ISSN 0258-7122

Bangladesh J. Agril. Res. 34(1) : 113-121, March 2009

\title{
EFFECT OF COMBINATIONS OF CHEMICAL FERTILIZERS AND POULTRY MANURE ON THE PRODUCTIVITY OF CROPS IN THE CAULIFLOWER-STEM AMARANTH-JUTE PATTERN
}

\author{
M. AKKAS ALI ${ }^{1}$, M.S.H. MOLLA ${ }^{2}$, M. ROBIUL A LAM ${ }^{3}$ \\ M. A. MOMIN ${ }^{4}$ AND M. A. MANNAN ${ }^{5}$
}

\begin{abstract}
Different combinations of chemical fertilizers and organic manure were applied for sustainable crop productivity in the cauliflower-stem amaranth -jute cropping pattern. The experiment was conducted at farmer's field in Multilocation Testing (MLT) site of Pakshi, Pahna over three years. There were five combinations of chemical fertilizers (CF) and poultry manure (PM) along with absolute control arranged in a randomized complete block design. The results revealed that all three crops showed significant yield for fertilizer and poultry manure use. Higher yields were obtained with 50\% CF + 50\% PM followed by $75 \%$ CF $+25 \%$ PM treatments where cauliflower equivalent yield was increased by $85 \%$ and $78 \%$, respectively, over control. This indicates a positive residual effect of poultry manure on the subsequent crops. From the economic points of view, the highest marginal benefit cost ratio (MBCR) was attained in $100 \%$ chemical fertilizer due to its lower variable cost followed by $75 \% \mathrm{CF}+25 \%$ PM treated plots. However, gross margin was higher in 50\% CF $+50 \%$ PM combination for its higher total yield.
\end{abstract}

Kew Words: Chemical fertilizer, poultry manure, productivity.

\section{Introduction}

Cauliflower-stem amaranth-jute cropping pattern is commonly practiced by the farmers of MLT site of Pakshi, Pabna. Nutrient demand of hybrid cauliflower and other improved crop varieties in the pattern is very high. Continuous use of chemical fertilizers at high rates in the pattern makes a sense of threat on soil health where no or very little organic recycling is practiced. Research results indicate that soil fertility of this country is being deteriorated with the advancement of time (Ali et al., 1997) which causes stagnating yield and in some cases decreasing crop yield (Cassman et al., 1997). Bair (1990) reported that sustainable production of a crop can not be maintained by using the chemical fertilizer alone and similarly it is not possible to obtain higher yield by using only

\footnotetext{
${ }^{1}$ Senior Scientific Officer, ${ }^{2 \& 3}$ ScieHtific Officer, ${ }^{4}$ Principal Scientific Officer, On-Farm Researc Division, Agricultural Research Station, BARI, Pabna, ${ }^{5}$ Senior Scientific Officer, Farm Division, BARI, Jovdebpur, Gazipur, Bangladesh.
} 
organic manure. Recently expansion of poultry farm even in the rural area, huge amount of poultry manure is being produced, which has high potential manure value. Few experiments were carried out at the Agricultural Research Station, Pabna, where poultry droppings based compost was used. The active poultry compost at $7.5 \mathrm{t} / \mathrm{ha}$ was found to be equally effective in increasing yield of rice and stem amaranth against 100\% chemical fertilizer dose (Momin, 2003). On the other hand, poultry droppings have become an environment polluting agent. Thus, the use of poultry manure in the crop field bears great significance. Therefore, a judicious integration of inorganic fertilizers along with organic manure and its effect on the succeeding crops in the cropping pattern deserves due importance for amending soil and sustained crop productivity. The experiment was undertaken to find out a suitable combinations of chemical fertilizers and organic manure for sustainable crop productivity in the cauliflower-stem amaranth-jute pattern, without affecting soil health.

\section{Materials and Method}

The experiment was carried out at Multilocation Testing (MLT) site, Pakshi, Pabna during 2003-04 to 2005-06 covering nine crop seasons in the High Ganges River Floodplain soil (AEZ.-11). The cropping pattern cauliflower-stem amaranth-jute was selected based on group discussion with local farmers, DAE personnel and available secondary information. A composite soil sample was collected from the experimental fields and analyzed. The soil was slightly alkaline, with very low organic matter, $\mathrm{N}$ and S; medium P; high $\mathrm{K}$ and low Zn status as per country's fertilizer Recommendation Guide (FRG, 1997). The experiment was laid out in a randomized complete block (RCB) design with four dispersed replications, unit plot size being $4 \mathrm{~m} \times 3 \mathrm{~m}$. Five different combinations with fertilizers and manure were employed against absolute control. Fertilizers were applied high yield goal basis (FRG, 1997) as shown below. 


\begin{tabular}{|c|c|c|c|c|c|c|c|c|c|c|c|c|c|c|c|c|c|c|c|c|c|}
\hline \multirow[t]{3}{*}{ Treatments } & \multicolumn{21}{|c|}{ Nutrient Rate (kg/ha) } \\
\hline & \multicolumn{7}{|c|}{ Rabi (Cauliflower) } & \multicolumn{7}{|c|}{ Kharif-I (Stem amaranth) } & \multicolumn{7}{|c|}{ Kharif-II (Jute) } \\
\hline & $\mathrm{N}$ & $\mathrm{P}$ & $\mathrm{K}$ & $\mathrm{S}$ & $\mathrm{Zn}$ & $\mathrm{B}$ & $\begin{array}{c}\mathrm{PM} \\
(\mathrm{t} / \mathrm{ha})\end{array}$ & $\mathrm{N}$ & $\mathrm{P}$ & $\mathrm{K}$ & $\mathrm{S}$ & \begin{tabular}{|l|}
$\mathrm{Z}$ \\
$\mathrm{n}$ \\
\end{tabular} & B & \begin{tabular}{|c|}
$\mathrm{PM}$ \\
$(\mathrm{t} / \mathrm{ha})$
\end{tabular} & $\mathrm{N}$ & $\mathrm{P}$ & $\mathrm{K}$ & $\mathrm{S}$ & $\mathrm{Zn}$ & B & $\begin{array}{c}\mathrm{PM} \\
(\mathrm{t} / \mathrm{ha})\end{array}$ \\
\hline $\mathrm{T}_{1}=100 \% \mathrm{CE}$ & 173 & 30 & 42 & 30 & 3 & 1 & - & 156 & 15.47 & 53 & 3 & - & - & - & 124 & 6 & 14 & 11 & - & - & - \\
\hline $\begin{array}{l}\mathrm{T}_{2}=75 \% \\
\mathrm{CF}+25 \% \mathrm{PM}\end{array}$ & 19.8 & 22.5 & 31.5 & 22.5 & 2.25 & .75 & 3.25 & 117 & 11.6 & 39.7 & 2.3 & & & 3 & 93 & 4.5 & 10.5 & 8.2 & & & 2.3 \\
\hline $\begin{array}{l}\mathrm{T}_{3}=50 \% \\
\mathrm{CF}+50 \% \mathrm{PM}\end{array}$ & 86.5 & 15 & 21 & 15 & 1.25 & .50 & 6.5 & 78 & 7.7 & 26.5 & 1.5 & & 6 & 62 & 3 & 7 & 5.5 & & & & 4.5 \\
\hline $\begin{array}{l}\mathrm{T}_{4}=25 \% \\
\mathrm{CF}+75 \% \mathrm{PM}\end{array}$ & 43.3 & 7.5 & 10.5 & 7.5 & .75 & .25 & 9.8 & 39 & 3.9 & 13.3 & .75 & & & 9 & 31 & 1.5 & 3.5 & 2.8 & & & 6.8 \\
\hline $\mathrm{T}_{5}=100 \% \mathrm{PM}$ & - & - & - & - & - & - & 13 & - & - & - & - & & & 12 & - & - & - & - & & & 9 \\
\hline $\mathrm{T}_{6}=$ Control & 0 & 0 & 0 & 0 & 0.0 & 0.0 & 0 & 0 & 0 & 0 & 0 & 0 & 0 & 0 & 0 & 0 & 0 & 0 & & & 0 \\
\hline
\end{tabular}

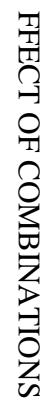

$\mathrm{CF}=$ Chemical fertilizer, $\mathrm{PM}=$ Poultry manure 
Poultry manure (compost) was prepared by taking fresh poultry dropping $50 \%$, chopped crop residues $50 \%$, urea $1 \%$, TSP $0.5 \%$, gypsum $1 \%$, and effective microorganism (EM) solution as needed. The poultry manure, thus prepared, contained $1.32 \% \mathrm{~N}$, which was used for calculation of required PM for different treatment combinations. Seedlings of cauliflower (var. White Contessa) were transplanted during 25 October to 5 November in line spacing maintaining $60 \mathrm{~cm}$ x $45 \mathrm{~cm}$ and harvested during 15-25 January in each year. Seeds of stem amaranth (var. BARI Data 1) were sown during 5-15 February in line with $30 \mathrm{~cm}$ spacing and continuous seeding at a seed rate of $2.25 \mathrm{~kg} / \mathrm{ha}$ and harvested during 27 March to 7 April. Every year, the jute seeds (var. 0-9897 and LIV) were sown on 10-30 April and harvested during 20 August to 10 September. In cauliflower, $1 / 2$ MoP, $1 / 2$ PM and the full amount of other fertilizers except urea were applied as basal. Full amound of urea, $1 / 2 \mathrm{MoP}$ and $1 / 2 \mathrm{PM}$ were applied as top dress in three equal installments at 10, 30, and 50 days after planting (DAP). For stem amaranth, $1 / 2$ urea, $1 / 2 \mathrm{MoP}$, and $1 / 2 \mathrm{PM}$ and full amount of other fertilizers were applied as basal. The rest $1 / 2$ urea. $1 / 2$ MoP and $1 / 2$ PM were applied as top dress in two equal splits at 20 and 30 days after sowing (DAS). In Jute $1 / 2$ urea, $2 / 3^{\text {rd }} P M$ and total amount of other fertilizers were applied as basal. The remaining urea and PM were applied as one top dress at 40 DAS. Intercultural operations, irrigation, and plant protection measures were done whenever required. Data on difierent parameters were collected following standard procedures and were statistically analyzed (Gomez and Gomez, 1984). Analysis of variance (ANOVA) and the comparison of treatment means by the least significant difference (LSD) were done by MStat statistical package. Cost and return analysis of diffeent treatments were computed on the basis of prevailing market price of cauliflower, stem amaranth and jute (fiber and sticks).

\section{Results and Discussion}

\section{Cauliflower}

Three years' pooled data showed that the yield and yield contributing characters as affected by different combinations of chemical fertilizers and poultry manure were significantly different (Table 1 and 4). The highest marketable weight, length and breadth of a curd obtained from 50\% CF + 50\% PM, which was statistically similar to other combinations except control. Cumulative effect of the yield attributes had resulted in increased curd yield for the fertilizer manure treatments. Although not significant, little higher yield was obtained from 50\% $\mathrm{CF}+50 \%$ PM combination which can be attributed to a balanced release of nutrients for both organic and inorganic sources.

\section{Stem amaranth}

Yield and yield attributes of stem amaranth showed significant variation among different treatments (Table 2). Higher yield was obtained from 50\% CF $+50 \%$ 
PM treatment, which was statistically similar to 75\% CF + 25\% PM, and $100 \%$ PM treatments. Higher plant population, plant height, and base circle produced higher yield. Yields obtained in the study confirmed the results reported by (Momin, 2003; Noor and Farid, 2002). These results clearly indicate that balanced uptake of nutrients from organic source had accelerated an optimum plant growth which ultimately produced increased yield. The lowest yield was observed in control.

Table 1. Effect of different combinations of fertilizers and poultry manure on the yield and yield attributes of cauliflower in the cauliflower-stem amaranthjute cropping pattern (mean of 3 years).

\begin{tabular}{l|l|l|l}
\hline \multicolumn{1}{c|}{ Treatments } & \multicolumn{1}{c|}{$\begin{array}{c}\text { Length of curd } \\
(\mathrm{cm})\end{array}$} & $\begin{array}{c}\text { Breadth of curd } \\
(\mathrm{cm})\end{array}$ & $\begin{array}{c}\text { Marketable wt. } \\
\text { curd/(kg) }\end{array}$ \\
\hline $\mathrm{T}_{1}=100 \% \mathrm{CF}$ & 11.1 & 16.5 & 1.3 \\
$\mathrm{~T}_{2}=75 \% \mathrm{CF}+25 \% \mathrm{PM}$ & 11.4 & 16.8 & 1.3 \\
$\mathrm{~T}_{3}=50 \% \mathrm{CF}+50 \% \mathrm{PM}$ & 11.9 & 18.3 & 1.4 \\
$\mathrm{~T}_{4}=25 \% \mathrm{CF}+75 \% \mathrm{PM}$ & 11.4 & 16.9 & 1.2 \\
$\mathrm{~T}_{5}=100 \%$ PM & 11.3 & 16.5 & 1.1 \\
$\mathrm{~T}_{6}=$ Control & 8.5 & 13.4 & 0.76 \\
\hline $\mathrm{CV}(\%)$ & 3.47 & 5.47 & 11.16 \\
LSD & 0.7 & 1.6 & 0.24 \\
\hline
\end{tabular}

Table 2. Effect of different combinations of fertilizers and poultry manure on the yield and yield attributes of stem amaranth in the cauliflower-stem amaranth-jute cropping pattern (mean of 3 years).

\begin{tabular}{l|l|l|l|l}
\hline \multicolumn{1}{c|}{ Treatments } & \multicolumn{1}{c|}{$\begin{array}{c}\text { Plant } \\
\text { population/ } \\
\mathrm{m}^{2} \text { (no.) }\end{array}$} & $\begin{array}{c}\text { Plant } \\
\text { height } \\
(\mathrm{cm})\end{array}$ & $\begin{array}{c}\text { Plant base } \\
\text { diameter } \\
(\mathrm{cm})\end{array}$ & \multicolumn{1}{c}{$\begin{array}{c}\text { Yield } \\
(\mathrm{t} / \mathrm{ha})\end{array}$} \\
\hline $\mathrm{T}_{1}=100 \%$ CF & 57.36 & 74.48 & 5.90 & 42.33 \\
$\mathrm{~T}_{2}=75 \%$ CF+25\% PM & 57.28 & 76.77 & 5.93 & 45.36 \\
$\mathrm{~T}_{3}=50 \%$ CF+50\%PM & 66.53 & 79.59 & 6.13 & 47.94 \\
$\mathrm{~T}_{4}=25 \%$ CF+75\% PM & 58.56 & 76.50 & 5.86 & 43.13 \\
$\mathrm{~T}_{6}=$ Control & 55.42 & 44.83 & 4.25 & 21.24 \\
\hline CV (\%) & 5.22 & 6.30 & 4.85 & 9.25 \\
LSD & 5.7 & 8.2 & 0.5 & 6.8 \\
\hline
\end{tabular}

\section{Jute}

Different treatments exhibited significant variation with yield and yield attributes of jute (Table 3). The highest fiber and stick yields were recorded in 50\% CF + $50 \%$ PM combination, which was statistically identical with $100 \%$ PM. The 
cumulative effect of higher plant population and longer size of plant had contributed to higher yield of jute in 50\% chemical fertilizer $+50 \%$ PM combination. Similar results were reported in jute, rice and vegetables crops (Noor and Farid, 2002; Momin 2003; and Meelu and Singh, 1991). The lowest fiber and stick yield was observed in control plots. The lowest yield and yield attributes were achieved in control plots. From the three years' mean results, it was found that $50 \% \mathrm{CF}+50 \% \mathrm{PM}$, and $100 \% \mathrm{PM}$ were promising combinations for jute production (Table 4).

Table 3. Effect of different combinations of fertilizers and poultry manure on the yield and yield attributes of jute in the cauliflower-stem amaranth-jute cropping pattern (mean of 3 years).

\begin{tabular}{l|l|l|l|l|l}
\hline \multicolumn{1}{c|}{ Treatments } & $\begin{array}{c}\text { Plant } \\
\text { population/ } \\
\mathrm{m}^{2} \text { (no.) }\end{array}$ & $\begin{array}{c}\text { Plant } \\
\text { height } \\
(\mathrm{cm})\end{array}$ & $\begin{array}{c}\text { Plant base } \\
\text { diameter } \\
(\mathrm{cm})\end{array}$ & $\begin{array}{c}\text { Stick } \\
(\mathrm{t} / \mathrm{ha})\end{array}$ & Yield \\
\hline $\mathrm{T}_{1}=100 \%$ CF & 38.94 & 3.07 & 3.49 & 6.15 & \\
$\mathrm{~T}_{2}=75 \%$ CF+25\% PM & 41.70 & 3.05 & 3.66 & 6.59 & \\
$\mathrm{~T}_{3}=50 \%$ CF+50\%PM & 45.12 & 3.16 & 4.14 & 7.65 & \\
$\mathrm{~T}_{4}=25 \%$ CF+75\% PM & 42.53 & 3.02 & 3.63 & 6.93 & \\
$\mathrm{~T}_{6}=$ Control & 44.20 & 3.05 & 3.74 & 7.17 & \\
\hline CV (\%) & 36.82 & 2.69 & 2.72 & 4.69 & \\
LSD & 6.81 & 3.48 & 7.83 & 6.95 & \\
\hline
\end{tabular}

\section{Equivalent yield}

Cauliflower equivalent yield (total productivity) did not vary remarkably among the different fertilizers and poultry manure combinations. As obtained with individual crops, higher yield was obtained from 50\% CF $+50 \%$ PM combination followed by $75 \% \mathrm{CF}+25 \% \mathrm{PM}$ combination where yield was increased by 85 and 78\%, respectively, over control (Fig. 1).

\section{Economic analysis}

From cost and return analysis, it was found that higher marginal benefit-cost ratio (MBCR) was obtained from $100 \%$ chemical fertilizers followed by $75 \%$ CF + 25\% PM combination and the decreasing MBCR trend were obtained with the increasing dose of PM (Table 5). Lower MBCR is mainly due to the higher variable cost of poultry manure. The lowest MBCR as found with $100 \% \mathrm{PM}$ was mainly due to higher amount and value of PM. But the highest gross return as well as gross margin was obtained from $50 \%$ CF $+50 \%$ PM combination. Although there was a lower cost for the $100 \%$ chemical fertilizer treatment, it showed lower gross margin due to lower total yield. Due to higher variable cost, 
Table 4. Effect of different combinations of fertilizers and poultry manure on cauliflower, stem amaranth, jute during 2003-2004 to 2005-2006.

\begin{tabular}{|c|c|c|c|c|c|c|c|c|c|c|c|c|}
\hline \multirow[t]{2}{*}{ Treatments } & \multicolumn{3}{|c|}{ 2003-04 } & \multicolumn{3}{|c|}{ 2004-05 } & \multicolumn{3}{|c|}{$2005-06$} & \multicolumn{3}{|c|}{ 2006-07 } \\
\hline & $\begin{array}{l}\text { Cauli } \\
\text { flower }\end{array}$ & $\begin{array}{c}\text { Stem } \\
\text { amaranth }\end{array}$ & Jute & $\begin{array}{l}\text { Cauli } \\
\text { flower }\end{array}$ & $\begin{array}{c}\text { Stem } \\
\text { amaranth }\end{array}$ & Jute & $\begin{array}{l}\text { Cauli } \\
\text { flower }\end{array}$ & $\begin{array}{c}\text { Stem } \\
\text { amaranth }\end{array}$ & Jute & $\begin{array}{l}\text { Cauli } \\
\text { flower }\end{array}$ & $\begin{array}{c}\text { Stem } \\
\text { amaranth }\end{array}$ & Jute \\
\hline \multicolumn{13}{|c|}{ curd/total/fibre (t/ha) } \\
\hline $\mathrm{T}_{1}=100 \% \mathrm{CF}$ & 47.25 & 27.96 & 2.45 & 50.81 & 49.00 & 3.98 & 49.03 & 50.04 & 4.03 & 49.03 & 42.33 & 3.49 \\
\hline $\mathrm{T}_{2}=75 \% \mathrm{CF}+25 \% \mathrm{PM}$ & 49.53 & 30.25 & 2.58 & 52.30 & 49.00 & 4.13 & 50.77 & 56.83 & 4.28 & 50.87 & 45.36 & 3.66 \\
\hline $\mathrm{T}_{3}=50 \% \mathrm{CF}+50 \% \mathrm{PM}$ & 49.64 & 31.41 & 2.90 & 52.99 & 50.00 & 4.68 & 51.32 & 62.42 & 4.84 & 51.32 & 47.94 & 4.14 \\
\hline $\mathrm{T}_{4}=$ Control & 27.46 & 14.64 & 2.35 & 29.39 & 22.00 & 2.92 & 28.43 & 27.08 & 2.88 & 28.43 & 21.24 & 3.63 \\
\hline $\mathrm{T}_{5}=100 \% \mathrm{PM}$ & 46.90 & 27.36 & 2.85 & 52.36 & 47.00 & 4.28 & 49.63 & 56.84 & 4.10 & 49.63 & 43.73 & 3.74 \\
\hline $\mathrm{T}_{6}=$ Control & 27.46 & 14.64 & 2.35 & 29.39 & 22.00 & 2.92 & 28.43 & 27.08 & 2.88 & 28.43 & 21.24 & 2.72 \\
\hline CV(\%) & 11.5 & 5.6 & 9.0 & 11.04 & 15.70 & 9.82 & 4.09 & 8.35 & 5.62 & 10.29 & 9.25 & 7.83 \\
\hline LSD & 6.091 & 2.74 & 0.43 & 8.080 & 10.40 & 0.43 & 1.766 & 6.439 & 0.343 & 1.089 & 6.834 & 0.508 \\
\hline \multicolumn{13}{|c|}{ Stick yield (t/ha) } \\
\hline $\mathrm{T}_{1}=100 \% \mathrm{CF}$ & - & - & 4.00 & - & - & 7.45 & - & - & 7.00 & - & - & 6.15 \\
\hline $\mathrm{T}_{2}=75 \% \mathrm{CF}+25 \% \mathrm{PM}$ & & & 4.67 & - & - & 8.30 & - & - & 6.80 & - & - & 6.59 \\
\hline $\mathrm{T}_{3}=50 \% \mathrm{CF}+50 \% \mathrm{PM}$ & - & - & 5.50 & - & - & 9.15 & - & - & 8.30 & - & - & 7.65 \\
\hline $\mathrm{T}_{4}=$ Control & - & - & 4.79 & - & - & 8.30 & - & - & 7.70 & - & - & 6.93 \\
\hline $\mathrm{T}_{5}=100 \% \mathrm{PM}$ & - & - & 5.80 & - & - & 9.05 & - & - & 6.65 & - & - & 7.17 \\
\hline $\mathrm{T}_{6}=$ Control & - & - & 3.00 & - & - & 6.04 & - & - & 5.03 & - & - & 4.69 \\
\hline CV(\%) & - & - & 11.7 & - & - & 10.0 & - & - & 9.20 & - & - & 6.95 \\
\hline LSD & - & - & 0.99 & - & - & 0.99 & - & - & 0.95 & - & - & 0.825 \\
\hline
\end{tabular}


the lower gross margin was found in the plots where 100\% PM was used. Overall results indicate that 75\% CF + $25 \%$ PM combination can help sustain soil health and crop productivity.

Table 5. Cost and return analysis of Cauliflower-Stem amaranth- Jute cropping pattern as affected by different treatment (average over 3 yrs.).

\begin{tabular}{|c|c|c|c|c|}
\hline Treatments & $\begin{array}{l}\text { Gross return } \\
(\mathrm{Tk} / \mathrm{ha})\end{array}$ & $\begin{array}{c}\text { Variable cost } \\
\text { (fertilizer cost } \\
\text { only) } \\
\text { (Tk/ha) }\end{array}$ & $\begin{array}{l}\text { Gross margin } \\
\text { (Tk/ha) }\end{array}$ & $\begin{array}{l}\text { MBCR (Over } \\
\text { control) }\end{array}$ \\
\hline \multicolumn{5}{|c|}{ Mean } \\
\hline $\mathrm{T}_{1}=100 \% \mathrm{CF}$ & 495833 & 16443 & 413811 & \multirow{3}{*}{$\begin{array}{l}12.38 \\
9.94 \\
8.23\end{array}$} \\
\hline $\mathrm{T}_{2}=75 \% \mathrm{CF}+25 \% \mathrm{PM}$ & 519810 & 22894 & 427862 & \\
\hline $\begin{aligned} \mathrm{T}_{3}= & 50 \% \mathrm{CF}+50 \% \\
& \mathrm{PM}\end{aligned}$ & 540840 & 30205 & 440703 & \\
\hline $\mathrm{T}_{4}=25 \% \mathrm{CF}+75 \% \mathrm{PM}$ & 504248 & 38229 & 392572 & 5.54 \\
\hline $\mathrm{T}_{5}=100 \& \mathrm{PM}$ & 509850 & 46517 & 382643 & 4.67 \\
\hline $\mathrm{T}_{6}=$ Control & 292200 & - & 248922 & - \\
\hline
\end{tabular}
(1) Urea
Price of input
(2) TSP
$=6.50 \mathrm{Tk} . / \mathrm{kg}$
$=16.50 \mathrm{Tk} \cdot / \mathrm{kg}$
(3) MP
$=15.00 \mathrm{Tk} . / \mathrm{kg}$
(4) Gypsum
$=05.00 \mathrm{Tk} . / \mathrm{kg}$
(5) Zinc sulphate
$=60.00 \mathrm{Tk} . / \mathrm{kg}$
(6) Borax
$=60.00 \mathrm{Tk} . / \mathrm{kg}$
(7) $\mathrm{PM}$
$=1.40 \mathrm{Tk} . / \mathrm{kg}$

(1) Cauliflow Price of output

(2) Stem amaranth

$=6.00 \mathrm{Tk} . / \mathrm{kg}$

(3) Jute fibre

(4) Jute stick

$=3.00 \mathrm{Tk} . / \mathrm{kg}$

$=18.75 \mathrm{Tk} . / \mathrm{kg}$

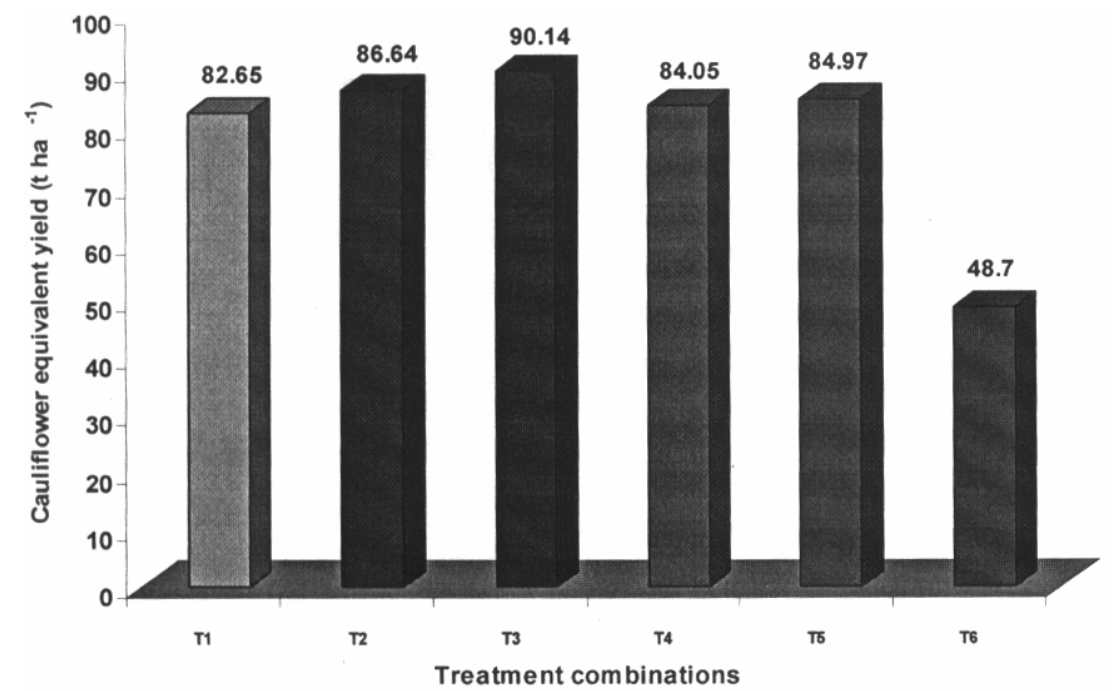

Fig. 1. Cauliflower equivalent yield (total productivity) of cauliflower-stem amaranthjute cropping pattern. 


\section{Conclusion}

From the three years' results, it appeared that the yield did not vary significantly among the different combinations of fertilizers and poultry manure, but every combination had significant positive result over absolute control. The combinations of both organic and inorganic fertilizer always showed better performance in case of gross return and gross margin although higher MBCR was obtained from $100 \%$ chemical fertilizers treated plots.

Crop yield and profit are both important to a farmer. Soil health is also very important for sustainable production. Thus, considering crop productivity, economic return and soil fertility together, $75 \%$ CF $+25 \%$ PM treatment could be recommended for the cauliflower-stem amaranth-jute cropping pattern in Pabna and similar soils of AEZ-1 I for sustainable crop yield and soil health.

\section{References}

Ali, M. M., S. M. Shaheed and D. Kabuta. 1997. Soil degradation during the period 19671995 in Bangladesh. II. Selected chemical characters. Soil Sci Plant Nutr 43: 870890.

Bair, W. 1990. Characterization of the environment for sustainable agriculture in SemiArid Tropics. In proc. Sustainable Agriculture Issues, perspectives and prospects in Semi-Arid tropics. Hyderabad, India. 1: 90-128.

Bangladesh Agricultural Research Council (BARC). 1997. Fertilizer Recommendation Guide- 1997. Farm gate, New Airport Road, Dhaka 1215.

Cassman, K. G. and P. L. Pingali. 1994. Extrapolating trends from long-term experiments to farmers' fields: the case study of irrigated rice systems in Asia. In:V. Barnett, R. Payne and R. Steiner (eds). Agricultural Sustainability in Economics, Environment, and Statistical terms. John Wiley and Sons. Ltd., London, U.K.

Gomez, K. A. and A. A. Gomez. 1984. Statistical Procedures for Agricultural Research. $2^{\text {nd }}$ Ed. John Wiley and Sons. Inc. New york.

Meelu, 0. P. and Y. Singh. 1991. Integrated use of fertilizers and organic manures for higher returns. Progressive Farming. Punjab Agric. Uni. 27: 3-4.

Momin, M. A. 2003. Effect of different composting techniques and chemical fertilizers on the yield and quality of rice and stem amaranth. A Ph.D Thesis, Department of Agronomy. Bangladesh Agricultural University, Mymensingh.

Noor, S., and A. T. M. Farid. 2002. Integrated nutrient management for homestead cropping pattern. Research Report 2001-2002. Soil Science Division, BARI. pp 8390. 